\title{
Pulmonary Alveolar Type II Cells Isolated from Rats
}

\author{
RELEASE OF PHOSPHATIDYLCHOLINE IN RESPONSE TO \\ $\beta$-ADRENERGIC STIMULATION
}

LELAND G. DoBBS and RoBERT J. MASON, Cardiovascular Research Institute,
University of California Medical Center, San Francisco, California 94143

A B S T RACT It is unclear what factors control the secretion of pulmonary surface active material from alveolar type II cells in vivo. Other workers have suggested that cholinergic stimuli, adrenergic stimuli, and prostaglandins may all stimulate secretion. We isolated type II cells from the lungs of rats by treatment with elastase, discontinuous density centrifugation, and adherence in primary culture. $\beta$-Adrenergic agonists, but not cholinergic agonists, caused an increase in the release of $\left[{ }^{14} \mathrm{C}\right]$ disaturated phosphatidylcholine, the major component of surface-active material, from type II cells in culture. The $\beta$-adrenergic effect was stereoselective, (-)-isoproterenol being 50 times more potent than $(+)$-isoproterenol. Terbutaline, $10 \mu \mathrm{M}$, a noncatecholamine $\beta$-2 adrenergic agonist, caused a release of $2.0 \pm 0.5($ mean $\pm \mathrm{SD})$ times the basal release of $\left[{ }^{14} \mathrm{C}\right]-$ disaturated phosphatidylcholine in $3 \mathrm{~h}$; the concentration of terbutaline causing half maximal stimulation was $800 \mathrm{nM}$. The terbutaline effect was blocked by propranolol, a $\beta$-adrenergic antagonist (calculated $K_{d}=6 \mathrm{nM}$ ), but not by phentolamine, an $\alpha$-adrenergic antagonist. Isobutylmethylxanthine, a phosphodiesterase inhibitor, and 8-Br cyclic AMP, but not $8-\mathrm{Br}$ cyclic guanosine monophosphate, also stimulated release. We conclude that type II cells secrete disaturated phosphatidylcholine in response to treatment with adrenergic stimulation.

\section{INTRODUCTION}

Although the alveolar type II cell is recognized to be the source of pulmonary surface-active material, it is unclear what factors control the secretion of surface-

Dr. Dobbs is the recipient of a Young Investigator Pulmonary Research grant (HL-19518) from the National Heart, Lung, and Blood Institute. Dr. Mason is an Established Investigator of the American Heart Association.

Received for publication 27 February 1978 and in revised form 27 September 1978. active material from type II cells. Several groups of investigators, working with whole adult animals, have shown that hyperventilation (1-3), cholinergic mechanisms (3-9), adrenergic mechanisms $(6,10-$ $15)$, and prostaglandins $(12,16)$ may all be important in the regulation of secretion of surface-active material. Such observations, apparently reflecting changes in secretion, might also be a result of alterations in synthesis, degradation, and(or) reuptake of the components of lung surfactant. The interpretation of studies with whole animals is further complicated by the cellular heterogeneity of the lung. Because the lung contains more than 40 different cell types (17), it is difficult, even in experiments with intact lungs or lung slices, to differentiate direct effects on type II cells from effects which might be mediated through other cells. Furthermore, in experiments with whole animals, it is likely that some effects might be mediated through organ systems other than the lung.

The problem of differentiating direct effects from indirect effects in the lung can be approached by a study of a homogenous population of isolated cells. We know of only one study to date of surfactant secretion with such a cell population, Smith's study (18) with the A549 cell line, a transformed cell line derived from a human pulmonary adenocarcinoma. We therefore decided to study the secretion of surface-active material by type II cells isolated from normal rats. Several authors have described methods of isolating alveolar type II cells (19-22); these authors all used the enzyme trypsin to dissociate type II cells from the lung. In preliminary experiments, we found that type II cells isolated by one of these methods (22) secreted disaturated phosphatidylcholine (DSPC $)^{1}$ in response to

${ }^{1}$ Abbreviations used in this paper: cAMP, cyclic AMP; cGMP, cyclic guanosine monophosphate; DME, Dulbecco's Modified Eagle's Medium; DSPC, disaturated phosphatidylcholine; $\mathrm{EC}_{50}$, concentration needed to produce half maximal stimulation; LDH, lactic dehydrogenase. 
treatment both with 12-O-tetradecanoyl-phorbol-13acetate and the calcium ionophore A 23187 (23), two substances that stimulate secretion in other cell systems. We were unable, at first, to demonstrate consistent effects on secretion with various other agents, including adrenergic agonists. Although other factors, such as better washing of cells and longer incubation periods, have also proved to be important, we thought that the use of trypsin in the initial cell isolation procedure might have altered the ability of the cells to respond to stimuli, a phenomenon that has been reported in other cell systems (24-26). We therefore developed a method of isolating type II cells with elastase instead of trypsin. In this paper we report that type II cells isolated with elastase secrete DSPC in response to treatment with adrenergic agonists; in a separate report, we will describe the details of the cell isolation procedure using elastase. We have published preliminary reports of these findings in abstract form $(27,28)$.

\section{METHODS}

Animals. We used male rats $(180-300 \mathrm{~g})$ of two different strains. We obtained Long-Evans rats from a colony maintained at the University of California until this colony was closed at the end of June 1977; after this time, we used Sprague-Dawley specific-pathogen-free rats from Hilltop Lab. Animals, Scottdale, Pa. Type II cells isolated from these strains responded similarly to adrenergic agonists and antagonists. In each experiment, we used from two to six rats to obtain type II cells.

Solutions used in the isolation of type II cells. All solutions were made with double-glass-distilled water. Solution I contained $\mathrm{NaCl}, 136 \mathrm{mM} ; \mathrm{KCl}, 5.3 \mathrm{mM}$; sodium phosphate buffer $\left(\mathrm{pH} 7.40\right.$ at $\left.22^{\circ} \mathrm{C}\right), 2.6 \mathrm{mM}$; Hepes $\left(\mathrm{pH} 7.40\right.$ at $\left.22^{\circ} \mathrm{C}\right), 10$ $\mathrm{mM}$. Solution II contained Solution I with $\mathrm{CaCl}_{2}, 1.9 \mathrm{mM}$, and $\mathrm{MgSO}_{4}, 1.3 \mathrm{mM}$. We made an albumin solution (fluorocarbonalbumin emulsion) with fatty-acid-free albumin, (Sigma Chemical Co., St. Louis, Mo.) $10 \mathrm{mg} / \mathrm{ml}$ Solution II. We then sonicated ("L converter," Branson Sonic Power Co., Danbury, Conn.) $2 \mathrm{ml}$ of fluorocarbon FC-75 (3M Co., St. Paul, Minn.) with $6 \mathrm{ml}$ of the albumin solution for $2 \mathrm{~min}$ at $75 \mathrm{~W}$ and diluted this with $30 \mathrm{ml}$ of albumin solution. This volume was sufficient for two rats. Elastase solution contained Solution II with elastase $40 \mathrm{U} / \mathrm{ml}$ (porcine pancreas, twice crystallized, aqueous suspension, Worthington Biochemical Corp., Freehold, N. J.). We measured tryptic (29) and chymotryptic (30, 31) activity in the lots of elastase used in these experiments and found no measurable activity $(<0.2 \% \mathrm{wt} / \mathrm{wt})$.

Cell isolation procedure. We used plastic or freshly siliconized glassware throughout the cell isolation procedure. We injected each rat intraperitoneally with $750 \mathrm{U}$ heparin (Invenex, Mogul Corp., Chagrin Falls, Ohio) and $15 \mathrm{mg}$ pentobarbital (Diamond Laboratories, Des Moines, Iowa). After the rats were anesthetized, we perfused and then removed the lungs as previously described (22).

We lavaged the lungs five times with Solution I, instilled $8-10 \mathrm{ml}$ of the fluorocarbon-albumin emulsion into the trachea, and incubated the lungs in $154 \mathrm{mM} \mathrm{NaCl}$ at $37^{\circ} \mathrm{C}$ for $20 \mathrm{~min}$. We removed the lungs from the saline and lavaged them eight times with Solution I to remove most of the fluorocarbon. The lungs were next lavaged with $8 \mathrm{ml}$ of elastase solution. After the lavage, we added elastase solution to total lung capacity (8-12 ml) and incubated the lungs in $154 \mathrm{mM} \mathrm{NaCl}$ at $37^{\circ} \mathrm{C}$ for $20 \mathrm{~min}$. At the end of this period, we minced the

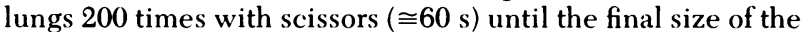
lung pieces was $\cong 1-2 \mathrm{~mm}^{3}$. We added $5 \mathrm{ml}$ of fetal calf serum (University of California Cell Culture Facility, San Francisco, Calif.) to inhibit further enzymatic activity, added Solution II to a volume of $20 \mathrm{ml}$, poured the minced lung tissue and cell suspension into a 250-ml Erlenmeyer flask, and shook the flask in a reciprocating water bath at 130 cycle/min for $2 \mathrm{~min}$ at $37^{\circ} \mathrm{C}$. We filtered the cell suspension through a series of three filters (cotton gauze, 100, and $20 \mu \mathrm{m}$ nylon mesh) (Tobler, Ernst, and Traber, Inc., Elmsford, N. Y.) to remove pieces of tissue and clumps of cells. Sterile discontinuous density gradients were made with albumin (Path-O-Cyte 4, Miles Laboratories, Kankakee, Ill.) by layering $10 \mathrm{ml}$ of albumin of $d$ 1.040-1.045 (range) onto $10 \mathrm{ml}$ of $d 1.085-1.089$ (range) in a 50-ml sterile conical centrifuge tube (Corning Glass Works, Corning, N. Y.). We layered the $20 \mathrm{ml}$ of the cell suspension $(20 \mathrm{ml})$ on top of each gradient.

From this point in the cell isolation procedure, we used sterile technique. We centrifuged the gradients at $270 \mathrm{~g}$ $(1,200 \mathrm{rpm})$ for $20 \mathrm{~min}$ in an International PR-Z centrifuge (International Equipment Co., Needham Hts., Mass.) at $4^{\circ} \mathrm{C}$. The top $26 \mathrm{ml}$ was discarded and $12 \mathrm{ml}$ of albumin containing the interface was removed and placed into a sterile $50-\mathrm{ml}$ centrifuge tube. Solution II was added to bring the volume to $45 \mathrm{ml}$, the cells were centrifuged at $130 \mathrm{~g}(800 \mathrm{rpm})$ for $6 \mathrm{~min}$, the supernatant liquid was removed, and the cell pellet was washed once more with Solution II. Cells were stained wich crystal violet and counted in a hemacytometer. The yield was $28 \pm 10 \times 10^{6}$ cells/rat (mean $\left.\pm \mathrm{SD} ; n=22\right), 96 \pm 3 \%(n=16)$ of which excluded the vital dye erythrosin $B(32)$. These cells were $80 \pm 8 \%(n=18)$ type II cells, as indicated by the modified Papanicolaou stain (20).

Primary culture of type II cells and release of DSPC. We suspended the cells $\left(2 \times 10^{6} \mathrm{cells} / \mathrm{ml}\right)$ in Dulbecco's Modified Eagle's Medium (DME, University of California Cell Culture Facility) containing $10 \%$ fetal calf serum, glutamine $(2 \mathrm{mM})$, and gentamicin $(10 \mu \mathrm{g} / \mathrm{ml})$, added the suspension to a $75 \mathrm{~cm}^{2}$ tissue culture flask (Falcon Plastics, Div. of BioQuest, Oxnard, Calif.) and placed the flask into a $10 \% \mathrm{CO}_{2}: 90 \%$ air incubator at $37^{\circ} \mathrm{C}$. This incubator was used for all cell incubations. After $1 \mathrm{~h}$, we removed the nonadherent cells and added to them $\cong 200 \mathrm{nmol}$ of ${ }^{14} \mathrm{C}$-methyl choline (New England Nuclear Corp., Boston, Mass.) (final specific activity in medium of $5-7 \mu \mathrm{Ci} / \mu \mathrm{M}$ choline) and sufficient medium to dilute the cells to a concentration of $0.75-1.0 \times 10^{6}$ cells $/ \mathrm{ml}$. We placed 1.5 $\mathrm{ml}$ of this cell suspension into each one of several $35-\mathrm{mm}$ plastic petri dishes (Corning) and incubated the dishes at $37^{\circ} \mathrm{C}$ for $22 \mathrm{~h}$. During this time, type II cells adhere to plastic and contaminating small round cells do not adhere. After $22 \mathrm{~h}$, we were thus able to remove the media and wash the adherent cells three to four times, leaving the type II cells adherent to the plastic. We found that the best way of removing the nonadherent cells was to tip each plate at a $45^{\circ}$ angle, to flood the top edge of the plate with $3-4 \mathrm{ml}$ of medium, to remove the medium, and to repeat this procedure until almost all the floating cells were removed; to check that washing was adequate, we inspected the plates with an inverted microscope. The adherent cells were $92 \pm 6 \%$ type II cells $(n=15)$; $99 \pm 1 \%$ (mean \pm range; $n=2$ ) excluded the vital dye erythrosin $B$.

We added $1.6 \mathrm{ml}$ of DME containing gentamicin $(10 \mu \mathrm{g} / \mathrm{ml})$ and albumin ( $3 \mathrm{mg} / \mathrm{ml}$ ) (Pentex Fraction V, Miles Laboratories) to each plate and allowed the cells to equilibrate at $37^{\circ} \mathrm{C}$ for $30 \mathrm{~min}$. In experiments with (-)- and (+)-isoproterenol, we added sodium ascorbate $(1 \mathrm{mM})$ to the incubation medium as an antioxidant (33). After the 30 -min equilibration period, we added $20 \mu \mathrm{l}$ of control solutions or solutions to test release of 
$\left[{ }^{14} \mathrm{C}\right] \mathrm{DSPC}$ from type II cells, swirled the plates to mix the added solutions, and returned the plates to the incubator. Every test solution was added to duplicate plates in each experiment. Solutions of antagonists were added immediately before agonists were added.

At the end of the incubation period, which varied in duration depending on the purpose of the experiment (see Results), we removed the medium from each plate and centrifuged it at $70 \mathrm{~g}$ for $5 \mathrm{~min}$ to sediment cells that may have become detached from the plate during the incubation period. We then removed $0.6 \mathrm{ml}$ of medium for isolation of DSPC and $0.3 \mathrm{ml}$ for measurement of lactic dehydrogenase (LDH) (34). Before centrifugation, floating cells in some samples of media amounted to $0.5-1.0 \%$ of total cells on the plate. After centrifugation, the supernatant medium contained $<0.25 \%$ of the cells that adhered to the plate. We extracted the cells from control plates by adding $1.5 \mathrm{ml}$ of $95 \%$ ethanol to each plate, scraping the cells off the bottom of the plate, and repeating this maneuver four times.

Lung fibroblast cell lines. Cell lines WI-38, passage 28 (35), and IMR-90, passage 14 (36), two diploid fibroblast lines derived from human lung tissue, were obtained from the University of California Cell Culture Facility, where the lines are stored at the temperature of liquid nitrogen. Cells were recovered in DME supplemented with $10 \%$ fetal calf serum in $75-\mathrm{cm}^{2}$ tissue culture flasks and grown to confluence ( $\left.\cong 6 \mathrm{~d}\right)$. For subculture, the cell monolayers were harvested with trypsin, plated onto $35-\mathrm{mm}$ plastic culture dishes at a $d$ $1 \times 10^{4}$ cells $/ \mathrm{cm}^{2}$ and grown to confluence. We added $\left[{ }^{14} \mathrm{C}\right]-$ choline (final specific activity in medium was $15 \mu \mathrm{Ci} / \mu \mathrm{M}$ ), washed the cells five times, added $1.5 \mathrm{ml}$ of nonradioactive medium containing albumin $3 \mathrm{mg} / \mathrm{ml}$, and tested secretion of $\left[{ }^{14} \mathrm{C}\right] \mathrm{DSPC}$ as described in the previous section. In each experiment we added solutions to duplicate plates of cells.

Isolation of DSPC. We added $4.0 \mathrm{ml}$ of methanol to each sample of medium and then added $8.0 \mathrm{ml}$ of chloroform. We evaporated the ethanolic extraction of cells to dryness under nitrogen and then added $12.0 \mathrm{ml}$ of chloroform:methanol $(2: 1)$ to the residue. To each sample of medium or cells, we added $\cong 1 \mathrm{mg}$ of mixed lipids isolated from dog lung as a carrier and a known amount of $\left[{ }^{3} \mathrm{H}\right] D S P C$ as an internal standard to calculate recoveries. The $\left[{ }^{3} \mathrm{H}\right] \mathrm{DSPC}(28.4 \mathrm{Ci} / \mathrm{mmol})$ was prepared by reacting egg phosphatidylcholine with ${ }^{3} \mathrm{H}$ gas (New England Nuclear Corp.) and was purified by previously described methods (37). We then extracted and isolated the lipids (38), evaporated each sample to dryness under nitrogen, reacted the residues with osmium tetroxide in carbon tetrachloride, and chromatographed the reaction products over neutral alumina columns to isolate DSPC (39). Samples were collected in glass scintillation vials, dioxane-water scintillation fluid (40) was added, and the radioactivity in the samples was counted in either a Packard Tricarb (Packard Instrument Co. Inc., Downers Grove, Ill.) or a Searle Mark II liquid scintillation counter (Searle Diagnostics Inc., G. D. Searle \& Co., Des Plaines, Ill.); the counts per minute in ${ }^{14} \mathrm{C}$ were corrected for recoveries based on the recovery of ${ }^{3} \mathrm{H}$ in each sample. There was no variation in quenching among samples, as determined by the use of an external standard. Recoveries ranged between 79 and $94 \%$. We expressed the $\left[{ }^{14} \mathrm{C}\right] \mathrm{DSPC}$ released by the cells as (counts per minute in medium/sum of counts per minute in cells of control plates and counts per minute in medium of control plates) $\times 100$. Control plates were incubated for the same period of time as test plates. There were no differences in total counts per minute in $\left[{ }^{14} \mathrm{C}\right] \mathrm{DSPC}$ of control plates or plates treated with terbutaline $(10 \mu \mathrm{M})$. Mean counts per minute in $\left[{ }^{14} \mathrm{C}\right] \mathrm{DSPC}$ of duplicate control and terbutaline-treated plates were: 0 time, $(104,000 ; 106,000)$; $1 \mathrm{~h},(106,000 ; 105,000) ; 2 \mathrm{~h},(106,000 ; 105,000) ; 3 \mathrm{~h},(98,300$;
$99,300) ; 4 \mathrm{~h},(97,800 ; 97,300)$. In each experiment, from two to five control plates were processed for cellular $\left[{ }^{14} \mathrm{C}\right] \mathrm{DSPC}$. Cellular $\left[{ }^{14} \mathrm{C}\right] \mathrm{DSPC}$ varied within an experiment by $7 \pm 5 \%$ (mean $\pm \mathrm{SD} ; n=15$ experiments, 52 plates).

Chemicals used to study release of DSPC. Atropine sulfate, 8-bromoadenosine-3':5'-cyclic monophosphoric acid, 8-bromoguanosine-3':5'-cyclic monophosphoric acid, carbamylcholine chloride, L-epinephrine bitartrate, methacholine chloride, L-norepinephrine bitartrate, L-phenylephrine $\mathrm{HCl}$, and DL-propranolol were purchased from Sigma Chemical Co. Isoproterenol bitartrate was obtained from two sources. One lot of (-)-isoproterenol, which we used in initial experiments, was purchased from Sigma Chemical Co. The other lot of (-)-isoproterenol, along with the (+)isoproterenol, was the generous gift of Dr. Paul Insel (University of California, San Francisco), who obtained both isomers from the Sterling-Winthrop Research Institute, Rensselear, N. Y.; we used this lot in experiments comparing the two stereoisomers. Pilocarpine- $\mathrm{HCl}$ was obtained from the Pharmacy of the University of California, San Francisco and was purchased from Alcon Labs, Inc., Ft. Worth, Tex. DLTerbutaline sulfate was the generous gift of Mr. Ralph Modlinger of Astra Pharmaceutical Products, Framingham, Mass. 12-O-tetradecanoyl-phorbol-13-acetate was purchased from the Consolidated Midland Corp., Brewster, N. Y. Dimethylsulfoxide was purchased from J. T. Baker Chemical Co. Phillipsburg, N. J. Isobutylmethylxanthine was purchased from Aldrich Chemical Co., Inc., Milwaukee, Wisc. Phentolamine$\mathrm{HCl}$ was the generous gift of Dr. Richard Fair, CIBA-Geigy Corp. (Summit, N. J.).

\section{RESULTS}

We used a different preparation of type II cells in each experiment. Therefore, $n$ represents the number of different cell preparations, each cell preparation consisting of pooled cells obtained from two to six rats. In initial experiments, we found that isoproterenol, epinephrine, norepinephrine, and terbutaline in concentrations of $10 \mu \mathrm{M}$ all stimulated release of $\left[{ }^{14} \mathrm{C}\right]-$ DSPC; carbamylcholine, pilocarpine, and methacholine in concentrations of $100 \mu \mathrm{M}$ did not stimulate release (Table I). It therefore appeared that, in our system, release was under adrenergic control. Because of the slow release of $\left[{ }^{14} \mathrm{C}\right] \mathrm{DSPC}$, it was necessary to use incubation periods of 1.5-3 h. Because catecholamines may be oxidized or degraded in this period of time, we used the shorter incubation time $(1.5 \mathrm{~h})$ for incubations with catecholamines. Because release of $\left[{ }^{14} \mathrm{C}\right] \mathrm{DSPC}$ was greater at $3 \mathrm{~h}$, it was easier to compare effects of agonists and antagonists after a 3-h incubation. We used terbutaline, a $\beta$-sympathomimetic amine not derived from catechol, as the adrenergic agonist in most of our studies because it is not degraded by catechol-O-methyl-transferase (41).

Time-course and magnitude of the release of $\left[{ }^{14} \mathrm{C}\right]-$ DSPC. The time-course of the release of $\left[{ }^{14} \mathrm{C}\right] \mathrm{DSPC}$ is shown in Fig. 1. Both the basal release and the magnitude of stimulation that terbutaline caused varied from experiment to experiment. Basal release was $1.9 \pm 0.5 \%($ mean $\pm \mathrm{SD}, n=15)$ of total cellular $\left[{ }^{14} \mathrm{C}\right]-$ 
TABLE I

Secretion of DSPC by Alveolar Type II Cells

\begin{tabular}{lcc}
\hline & $\begin{array}{c}\text { No. of } \\
\text { experiments }\end{array}$ & $\begin{array}{c}\text { Secretion in } \\
\text { controls } \\
\text { (mean } \pm \text { range) }\end{array}$ \\
\hline Control & 5 & $\%$ \\
Pilocarpine, $100 \mu \mathrm{M}$ & 2 & 100 \\
Carbamylcholine, $100 \mu \mathrm{M}$ & 4 & $97 \pm 0$ \\
Methacholine, $100 \mu \mathrm{M}$ & 2 & $100 \pm 21$ \\
L-Epinephrine, $10 \mu \mathrm{M}$ & 2 & $239 \pm 32^{*}$ \\
L-Isoproterenol, $10 \mu \mathrm{M}$ & 2 & $300 \pm 20^{*}$ \\
DL-Terbutaline, $10 \mu \mathrm{M}$ & 2 & $310 \pm 5^{*}$ \\
Tetradecanoyl phorbol acetate, & & \\
$\quad$ 10 nM & 5 & $495 \pm 123^{*}$ \\
\hline
\end{tabular}

All experiments (each experiment with a different preparation of type II cells) were performed with duplicate samples as described in the text. Control media contained $1.6 \mathrm{ml}$ DME to which we added $20 \mu \mathrm{l}$ of $\mathrm{NaCl}(154 \mathrm{mM})$; we added other test solutions in a volume of $20 \mu \mathrm{l}$. The incubation period was $90 \mathrm{~min}$. The range of total cellular counts per minute in $\left[{ }^{14} \mathrm{C}\right] D S P C$ was $19,600-113,000$. The release of $\left[{ }^{14} \mathrm{C}\right] \mathrm{DSPC}$ varied among experiments; mean release in control plates was $2.1 \%$ of total cellular $\left[{ }^{14} \mathrm{C}\right] \mathrm{DSPC}(\mathrm{SD}=1.0 \%$; range $0.75-$ $3.35 \% ; n=5)$. We expressed the secretion of $\left[{ }^{14} \mathrm{C}\right] \mathrm{DSPC}$ as the percent of the release observed in controls. The data were analyzed by a one-way analysis of variance and a twotailed Dunnett's test.

$* P<0.01$, different from controls.

DSPC in $3 \mathrm{~h}$; terbutaline-induced stimulation was $2.0 \pm 0.5$ times the basal release $(n=11)$. The stimulation induced by terbutaline falls within the range of results from in vivo experiments $(3,8)$, in which release stimulated by a variety of factors was between 1.4 and 2.5 times basal release in $2 \mathrm{~h}$.

Comparison of $\alpha$ - and $\beta$-adrenergic agonists. We next compared the stimulatory effect of DL-terbutaline, a $\beta$-2-adrenergic agonist, with phenylephrine, an $\alpha$ adrenergic agonist (Fig. 2). The concentration of terbutaline needed to produce half maximal stimulation $\left(\mathrm{EC}_{50}\right)$ was $0.8 \mu \mathrm{M}$, a value which is a little lower than the range of $2-12 \mu \mathrm{M}$ described in other cell systems $(42,43)$. The decrease in stimulation seen at the highest concentrations (termed "autoinhibition") of terbutaline has been observed with various $\beta$-adrenergic agonists; autoinhibition may be a result of competitive inhibition by the D-isomer at high concentrations, but other explanations (44) are possible and we do not know the reason in this case.

Phenylephrine was less potent than terbutaline; the $\mathrm{EC}_{50}$ of phenylephrine was $13 \mu \mathrm{M}$. The stimulation induced by phenylephrine $(10 \mu \mathrm{M})$ was blocked by propranolol $(50 \mu \mathrm{M})$, a $\beta$-adrenergic antagonist, but, in a single experiment, was not blocked by phentolamine, an $\alpha$-adrenergic antagonist (data not shown). Therefore, phenylephrine would appear to act through $\beta$-adrenergic mechanisms; many agonists, at higher concentrations, lose specificity $(44,45)$.

Stereospecificity. The $\beta$-adrenergic receptor system is stereospecific, $(-)$-isomers being considerably more potent than $(+)$-isomers $(45,46)$. A comparison of $(-)$ - and (+)-isoproterenol is shown in Fig. 3; the incubation time for these experiments was $1.5 \mathrm{~h}$. The $\mathrm{EC}_{50}$ of the (-)-isomer was $4 \mathrm{nM}$; the $\mathrm{EC}_{50}$ of the (+)isomer was $200 \mathrm{nM}$. The (-)-isomer was $\cong 50$ times more potent than the $(+)$-isomer. The release of $\left[{ }^{14} \mathrm{C}\right]-$ DSPC stimulated by isoproterenol in these two experiments was less than that observed with L-isoproterenol obtained from Sigma Chemical Co. (Table I).

Inhibition of the terbutaline effect by propranolol. The release induced by terbutaline was inhibited by DL-propranolol, as shown in Fig. 4. With the equations of Cheng and Prusoff (47) and the EC $_{50}$ of terbutaline

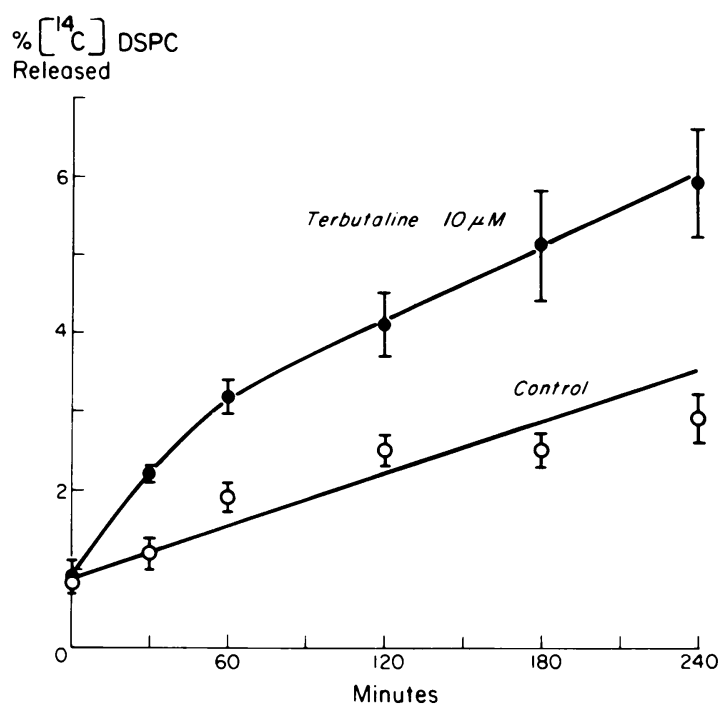

Figure 1 Time-course of the release of $\left[{ }^{14} \mathrm{C}\right] \mathrm{DSPC}$. The percent of total cellular $\left[{ }^{14} \mathrm{C}\right] D S P C$ released into the medium is indicated on the ordinate. The duration of the incubation period with terbutaline or control solutions is indicated on the abscissa. The incubation period was begun after the cells were washed and placed at $37^{\circ} \mathrm{C}$ to equilibrate for $30 \mathrm{~min}$. For details, see text. Basal release of $\left[{ }^{14} \mathrm{C}\right] \mathrm{DSPC}$ is indicated by $O$; release stimulated by DL-terbutaline $[10 \mu \mathrm{M}]$ is shown by - Each point represents the mean of six samples; the samples were duplicate samples from three experiments, each experiment with a different preparation of type II cells. Bars denote the standard errors of the means. Values for control and terbutaline-treated cells, when compared by an unpaired Student's $t$ test, were statistically significantly different at the $P<0.01$ level for all time points except zero time. Mean counts per minute in $\left[{ }^{14} \mathrm{C}\right] \mathrm{DSPC}$ of duplicate control and terbutaline-treated plates were not different; for details, see text. The means of total counts per minute in control plates were, for the three experiments at zero time: $22,7(0), 23,000$, and 105,000 . 
$\%$ Secretion Induced by

Terbutaline $[100 \mu \mathrm{M}]$

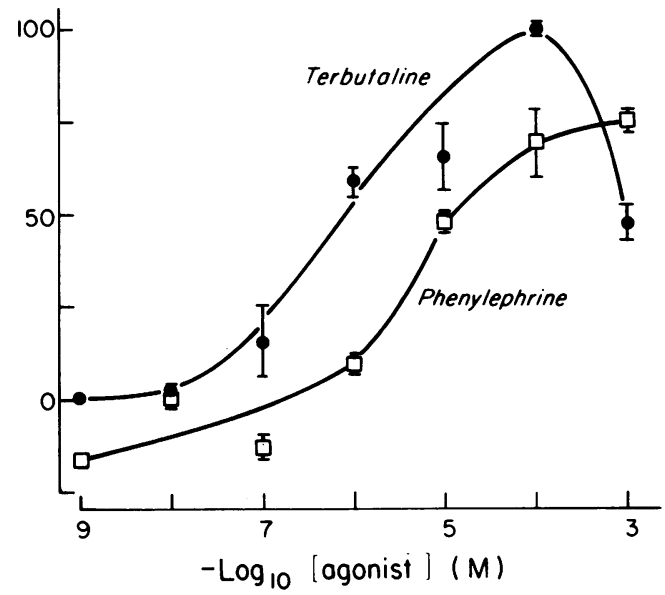

Figure 2 Dose-response curves of DL-terbutaline and phenylephrine. The release of $\left[{ }^{14} \mathrm{C}\right] \mathrm{DSPC}$ induced by DLterbutaline [100 $\mu \mathrm{M}$ ] minus the basal release at the end of a 3-h incubation was normalized to $100 \%$ and is indicated on the ordinate. The concentrations of terbutaline and phenylephrine in samples of cells are expressed on the abscissa. Terbutaline $(\Theta)$ induced a release that was maximal at a concentration of $100 \mu \mathrm{M}$; the $\mathrm{EC}_{50}$ was $0.8 \mu \mathrm{M}(800 \mathrm{nM})$. Phenylephrine ( $\square$ ) induced a maximal release that was $74 \%$ of the maximal release induced by terbutaline; the $\mathrm{EC}_{50}$ of phenylephrine was $13 \mu \mathrm{M}$. Each point represents the mean of duplicate samples from each of two experiments with different preparations of type II cells. Values for terbutaline and phenylephrine, when compared by an unpaired Student's $t$ test, were statistically significantly different at the $P<0.01$ level for all points except those at $10 \mu \mathrm{M}$, which were significant at the $P=0.02$ level. In the two experiments, the means of total cellular $\left[{ }^{14} \mathrm{C}\right] \mathrm{DSPC}$ in control plates were 38,200 and 76,300 cpm; cells treated with control solutions released 1.2 and $2.3 \%$ of total cellular counts per minute; $100 \mu \mathrm{M}$ terbutaline induced 2.1 and $4.6 \%$ secretion, respectively.

from Fig. 2, one can calculate the apparent $K_{d}$ of propranolol for the type II cell; this was $6 \mathrm{nM}$. This value is within the range of $2-8 \mathrm{nM}$ reported in other systems $(42,46,48)$. Phentolamine, even at high concentrations, did not inhibit the release induced by terbutaline (Fig. 4) nor did atropine $(10 \mu \mathrm{M})$, a cholinergic antagonist $(10 \mu \mathrm{M}$ terbutaline, $3.8 \pm 0.2 \%$ of the total cellular $\left[{ }^{14} \mathrm{C}\right] \mathrm{DSPC} ; 10 \mu \mathrm{M}$ terbutaline $+10 \mu \mathrm{M}$ atropine, $3.8 \pm 0.1 \%$ [mean $\pm \mathrm{SD}, n=3]$ ]).

It is unclear why higher concentrations of propanolol (1 $\mathrm{mM}$ ) did not inhibit release. Although there are reports of mild stimulation by high concentrations of certain adrenergic antagonists, propranolol is not among the compounds reported to cause such stimulation (44). The enhanced release of DSPC in this case is apparently not merely a toxic effect because there was no increase in LDH in the medium.

Effect of cyclic nucleotides. Stimulation of the $\beta$ adrenergic receptor appears to be associated with an increase in the activity of adenylate cyclase (26). We found that treatment with exogenous $8-\mathrm{Br}$ cyclic (c)AMP caused a significant increase in the release of $\left[{ }^{14} \mathrm{C}\right] \mathrm{DSPC}$, whereas treatment with $8-\mathrm{Br}$ cyclic guanosine monophosphate (cGMP) had no effect. Isobutylmethylxanthine, a phosphodiesterase inhibitor, also increased the amount of $\left[{ }^{14} \mathrm{C}\right] \mathrm{DSPC}$ released by type II cells; 8-Br cAMP enhanced the effect of isobutylmethylxanthine (Table II).

Determination of $L D H$ in medium and cells. We measured the amount of LDH in medium and cells as a measure of possible cellular toxicity; if cells are damaged, a cytoplasmic enzyme such as LDH may be released into the medium. We found between 0.5 and $3.0 \%$ of total cellular LDH in the medium after we incubated cells with control solutions for $3 \mathrm{~h}$. The only chemicals that caused release of LDH above control levels were phenylephrine, (+)-isoproterenol, and dimethylsulfoxide. Phenylephrine, in concentrations $<100 \mu \mathrm{M}$, did not increase the release of $\mathrm{LDH} ; 100$ $\mu \mathrm{M}$ concentrations induced a release that was double,

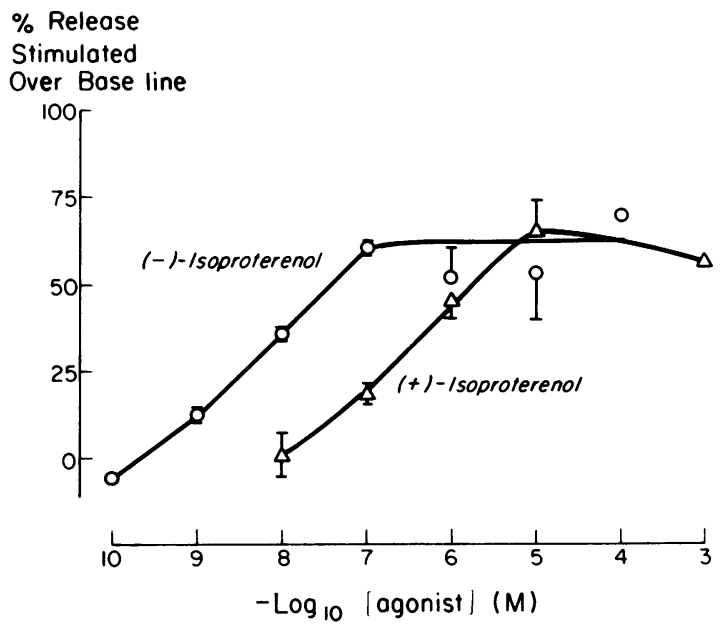

Figure 3 Dose-response curves of (-)-isoproterenol and (+)-isoproterenol. The release of $\left[{ }^{14} \mathrm{C}\right] \mathrm{DSPC}$ in $90 \mathrm{~min}$ is expressed on the ordinate as "percent release stimulated over base line" or ([stimulated release-control release]/control release) $\times 100$. Concentrations of $(-)$-isoproterenol $(O)$ and $(+)$-isoproterenol $(\Delta)$ are noted on the abscissa. Each point is the mean of two experiments with different preparations of type II cells. Each experiment was performed with duplicate samples. Bars denote the range of the two experiments. When values for the two stereoisomers were compared by an unpaired Student's $t$ test, only the points at $0.1 \mu \mathrm{M}$ were statistically significantly different at the $P<0.05$ level. In the two experiments, the means of total cellular $\left[{ }^{14} \mathrm{C}\right] \mathrm{DSPC}$ in duplicate samples were 66,200 and $113,000 \mathrm{cpm}$; cells treated with control solutions released 1.4 and $3.2 \%$ of total cellular counts per minute, respectively. Points without bars indicate the mean of duplicate samples from one experiment only. The concentration of (-)-isoproterenol causing half maximal stimulation was $4 \mathrm{nM}$; the concentration of $(+)$-isoproterenol causing half-maximal stimulation was $200 \mathrm{nM}$. 
$\%\left[{ }^{14} \mathrm{C}\right]$ DSPC Releosed

into Medium

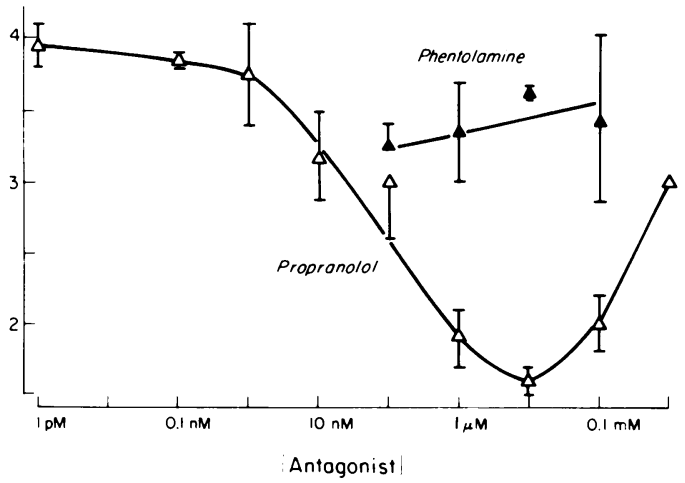

FIGURE 4 Action of $\alpha$-and $\beta$-adrenergic antagonists on the terbutaline-stimulated release of $\left[{ }^{14} \mathrm{C}\right] \mathrm{DSPC}$. All samples were incubated with terbutaline $(10 \mu \mathrm{M})$ for $3 \mathrm{~h}$. Solutions of phentolamine, an $\alpha$-adrenergic antagonist, or DL-propranolol, a $\beta$-adrenergic antagonist, were added to duplicate samples in each of two experiments with different preparations of type II cells just before the addition of DL-terbutaline (for details, see text). In the two experiments, the means of total cellular $\left[{ }^{14} \mathrm{C}\right] \mathrm{DSPC}$ in duplicate samples were 37,400 and $38,300 \mathrm{cpm}$; cells treated with control solutions released 1.2 and $1.6 \%$ of total cellular counts per minute; and $10 \mu \mathrm{M}$ terbutaline induced 3.3 and $3.8 \%$ secretion, respectively. The release of $\left[{ }^{14} \mathrm{C}\right] \mathrm{DSPC}$ is expressed on the ordinate. Concentrations of phentolamine $(\boldsymbol{\Delta})$ and propranolol $(\triangle)$ are indicated on the abscissa. Error bars denote the range between the two experiments. Phentolamine did not inhibit the terbutalineinduced release of $\left[{ }^{14} \mathrm{C}\right] \mathrm{DSPC}$. Propranolol, at concentrations of $0.1 \mu \mathrm{M}$ to $0.1 \mathrm{mM}$ inhibited the terbutaline-induced release $\left(P<0.01\right.$ by a paired Student's $t$ test). One can calculate the $K_{d}$ of propranolol and the $\beta$-receptor by using the equations of Cheng and Prusoff (47): $K_{d}=K_{m} \mathrm{I}_{50} /\left(K_{m}+\mathrm{S}\right)$, where $\mathrm{S}=$ substrate concentration; $K_{m}=$ dissociation constant of substrate, here assumed equal to the $\mathrm{EC}_{50}$ of terbutaline in Fig. $2 ; \mathrm{I}_{50}$ = concentration of inhibitor causing half maximal inhibition of substrate. The $K_{d}$ for propranolol calculated in this manner is $6 \mathrm{nM}$.

and $1 \mathrm{mM}$ concentrations induced a release of $\mathrm{LDH}$ that was eight times control values. All concentrations of $(+)$-isoproterenol $<1 \mathrm{mM}$ did not cause an increase in LDH release; $1 \mathrm{mM}(+)$-isoproterenol caused cells to release double the amount of LDH that controls released. Because we dissolved isobutylmethylxanthine in dimethylsulfoxide, all media that contained isobutylmethylxanthine also contained $1.25 \%(\mathrm{vol} / \mathrm{vol})$ dimethylsulfoxide. This concentration of dimethylsulfoxide caused cells to release three times the amount of LDH that controls released; the addition of isobutylmethylxanthine did not further increase the amount of LDH released.

Release of $\left[{ }^{14} \mathrm{C}\right] D S P C$ from lung fibroblasts. WI38 cells released $0.8 \pm 0.1 \%$ (mean $\pm \mathrm{SD} ; n=3$ ) of total cellular $\left[{ }^{14} \mathrm{C}\right] \mathrm{DSPC}$ when treated with control solutions for $1.5 \mathrm{~h}$ and $0.8 \pm 0.1 \%(n=3)$ when treated with $10 \mu \mathrm{M}$ terbutaline. Cells treated with control solutions contained $8,040 \pm 2,100 \mathrm{cpm}($ mean $\pm \mathrm{SD} ; n=3)$ in DSPC and cells treated with terbutaline contained $8,700 \pm 2,160 \mathrm{cpm}($ mean $\pm \mathrm{SD}, n=3)$. The control and treated cells were not statistically different in cellular content of $\left[{ }^{14} \mathrm{C}\right] \mathrm{DSPC}$ or in percent of $\left[{ }^{14} \mathrm{C}\right] \mathrm{DSPC}$ released, when compared by a paired $t$ test.

IMR 90 cells released $1.0 \pm 0.3 \%($ mean $\pm S D ; n=3)$ of total cellular $\left[{ }^{14} \mathrm{C}\right] \mathrm{DSPC}$ when treated with control solutions for $1.5 \mathrm{~h}$ and $0.8 \pm 0.2 \%$ when treated with 10 $\mu \mathrm{M}$ terbutaline. Cells treated with control solutions contained $11,600 \pm 1,710 \mathrm{cpm}$ as DSPC (mean $\pm \mathrm{SD}$; $n=3$ ), and cells treated with terbutaline contained $11,100 \pm 1,800 \mathrm{cpm}$. The control and treated cells were not statistically different in cellular content of $\left[{ }^{14} \mathrm{C}\right]-$ DSPC or in percent of $\left[{ }^{14} \mathrm{C}\right] \mathrm{DSPC}$ released when compared by a paired $t$ test.

\section{DISCUSSION}

We have shown that pulmonary alveolar type II cells can be isolated in high purity from the lungs of rats by

TABLE II

Effect of Cyclic Nucleotides on Release of $\left[{ }^{14} \mathrm{C}\right] \mathrm{DSPC}$

\begin{tabular}{|c|c|c|}
\hline Agonist concentration & $\begin{array}{l}\text { No. of } \\
\text { experiments }\end{array}$ & $\begin{array}{l}\text { Secretion in } \\
\text { controls } \\
(\text { mean } \pm \text { SD) }\end{array}$ \\
\hline Control & 4 & 100 \\
\hline$+8-\mathrm{Br}$ cAMP, $100 \mu \mathrm{M}$ & 4 & $188 \pm 29 *$ \\
\hline + 8-Br cGMP, $100 \mu \mathrm{M}$ & 4 & $103 \pm 10$ \\
\hline Dimethylsulfoxide, $1.25 \%$ & 4 & $146 \pm 19$ \\
\hline $\begin{array}{l}+ \text { isobutylmethylxanthine, } \\
100 \mu \mathrm{M}\end{array}$ & 4 & $213 \pm 30 *$ \\
\hline $\begin{array}{l}\text { + isobutylmethylxanthine, } \\
100 \mu \mathrm{M}+8-\mathrm{Br} \text { cAMP }\end{array}$ & & \\
\hline $\begin{aligned} & 100 \mu \mathrm{M} \\
+ & \text { isobutylmethylxanthine, } \\
& 100 \mu \mathrm{M}+8-\mathrm{Br} \text { cGMP, } \\
& 100 \mu \mathrm{M}\end{aligned}$ & 4 & $272 \pm 56 * \ddagger \S$ \\
\hline
\end{tabular}

Cells were incubated with agonists for $90 \mathrm{~min}$ as indicated in the text. Control media contained $1.6 \mathrm{ml}$ DME to which we added $20 \mu \mathrm{l}$ of $\mathrm{NaCl}(154 \mathrm{mM})$; we also added solutions of agonists in volumes of $20 \mu \mathrm{l}$. We dissolved isobutylmethylxanthine in dimethylsulfoxide; therefore, all solutions that contained isobutylmethylxanthine also contained $1.25 \%$ ( $\mathrm{vol} / \mathrm{vol}$ ) dimethylsulfoxide. Total counts per minute in $\left[{ }^{14} \mathrm{C}\right] \mathrm{DSPC}$ and percent released in control plates were, for each of four experiments with different cell preparations (mean of duplicate samples): $55,800 \mathrm{cpm}, 2.0 \% ; 66,100 \mathrm{cpm}$, $0.8 \% ; 67,300 \mathrm{cpm}, 1.5 \% ; 113,000 \mathrm{cpm}, 3.2 \%$. We analyzed these data by a two-way analysis of variance, a two-tailed Dunnett's test, and a Newman-Keul's test. Release in plates with dimethylsulfoxide alone was not statistically different from controls.

${ }^{*} P<0.01$, when compared to controls.

$\ddagger P<0.005$, when compared to dimethylsulfoxide.

$\$ P<0.001$, when compared to isobutylmethylxanthine or to isobutylmethylxanthine +8 -Br cGMP. 
treatment with elastase, an enzyme that few workers (49-51) have reported using to isolate cells. Alveolar type II cells so isolated release DSPC in response to $\beta$-adrenergic agonists in concentrations similar to the physiologic concentration of epinephrine (52); the response is stereoselective, is inhibited by a $\beta$-adrenergic antagonist, and is not inhibited by an $\alpha$-adrenergic antagonist. It is likely that the release of DSPC is the result of $\beta-2$ rather than $\beta$ - 1 adrenergic stimulation, because terbutaline is a fairly selective $\beta$-adrenergic agonist (53), but this issue would be best decided by the results of experiments with selective $\beta-1$ and $\beta-2$ blocking agents. The release of DSPC is also stimulated by 8-Br cAMP and a phosphodiesterase inhibitor, but is not stimulated by $8-\mathrm{Br}$ cGMP. Although these data are consistent with the hypothesis that the release of DSPC is under adrenergic control, the effects of both the cell isolation procedure and the subcellular localization of $\left[{ }^{14} \mathrm{C}\right] \mathrm{DSPC}$ on the interpretation of the present studies must be considered.

Proteolytic enzymes used in cell isolation procedures may alter the responses of cells. Whether such enzymatic effects are stimulatory or inhibitory, reversible or irreversible, varies, depending on both the function and the cell system studied. We are not aware of descriptions of the effects of elastase on whole cells. However, Hanoune et al. have reported (54) that treatment of liver plasma membranes with crude collagenase or with "chromatographically pure elastase" stimulates membrane adenylate cyclase activity; the magnitude of the response to epinephrine was greater after enzymatic treatment, but the dose-response relationship to epinephrine was not shifted. These authors inferred that the effect of enzymatic treatment was because of increased numbers of available catalytic sites (perhaps "unmasked" after enzymatic treatment) or increased catalytic content of adenylate cyclase, rather than because of an altered affinity of the membrane receptors. We cannot exclude that a similar effect could be operating in our system. While trypsin did not stimulate cyclase activity in the liver plasma membrane system, trypsin has been shown, in some systems (55), to increase responsiveness to $\beta$-adrenergic agonists and, in other systems, to decrease responsiveness (24-26). We recently have been able to show that type II cells isolated with crystalline trypsin (22) also secrete DSPC when treated with terbutaline ${ }^{2}$ and, although we have not characterized the response of cells isolated with trypsin in the same fashion as we have with cells isolated with elastase, we believe that the response to

\footnotetext{
${ }^{2}$ In two experiments with different cell preparations, control cells released 1.4 and $0.9 \%$ of total cellular $\left[{ }^{14} \mathrm{C}\right] \mathrm{DSPC}$, and cells treated with $10 \mu \mathrm{M}$ terbutaline released 2.4 and $1.5 \%$, respectively.
}

$\beta$-adrenergic stimuli is unlikely to be merely an artifact of the isolation procedure.

The percentage of total cellular $\left[{ }^{14} \mathrm{C}\right] \mathrm{DSPC}$ released by type II cells treated with adrenergic agonists is small and the release occurs slowly, over hours. Although our findings are consistent with published reports on secretion stimulated in vivo $(3,6,8)$, it is possible that the effect that we and others have observed is because of a shift in pools of DSPC, rather than because of an increase of secretory activity. We did not find differences in total cellular content of $\left[{ }^{14} \mathrm{C}\right]-$ DSPC in control and terbutaline-treated cells. However, it should be kept in mind that DSPC is not unique to surface-active material, but is also found in some cell membranes. We do not know the subcellular compartmentalization of $\left[{ }^{14} \mathrm{C}\right] \mathrm{DSPC}$ in type II cells. Young and Tierney (56) suggested that there was more than one pool of dipalmitoylphosphatidylcholine in the rat lung. They recovered only $\cong 40 \%$ of total labeled dipalmitoylphosphatidylcholine in lung lavage in $24 \mathrm{~h}$. Jobe (57) found that only $30-40 \%$ of labeled phosphatidylcholine was recoverable from the alveolar space of rabbit lungs. We have observed a maximal release of $36 \%$ of total cellular $\left[{ }^{14} \mathrm{C}\right] \mathrm{DSPC}(58)$. Therefore, it is possible that only $\cong 40 \%$ of $\left[{ }^{14} \mathrm{C}\right] \mathrm{DSPC}$ in isolated type II cells could be secreted in $24 \mathrm{~h}$. There are several possible explanations of these findings, including incorporation of label into cell components other than surface-active material, secretion of different pools of surfactant at different rates, reuptake or degradation of DSPC after secretion, and multiple stimulatory and inhibitory influences on secretion. Determination of the specific activities of secreted material and knowledge of the subcellular localization of the components of surface-active material would help to decide which alternatives are correct, but present methods of obtaining type II cells do not yield adequate numbers of cells to make these kinds of measurements. Therefore, although we believe that $\beta$-adrenergic stimulation increases secretion of $\left[{ }^{14} \mathrm{C}\right] \mathrm{DSPC}$ from intracellular pools of surface-active material, we cannot exclude coexistent effects on intracellular pools.

We found that lung fibroblasts also release a small amount of $\left[{ }^{14} \mathrm{C}\right] \mathrm{DSPC}$; this is less than type II cells release, and the release is not stimulated by $10 \mu \mathrm{M}$ terbutaline. We do not know the source of the DSPC from fibroblasts. Cell ghosts or fragments that do not sediment at $70 \mathrm{~g}$ seem a likely source, but we cannot rule out an exchange with trace amounts of lipids in the incubation medium or secretion by fibroblasts.

It has been suggested by other workers that adrenergic stimulation may enhance release of surface-active material. Kero et al. (10) reported that there were no cases of respiratory distress syndrome of the newborn among a group of premature (28-32-wk gestational age) infants whose mothers had received isoxsuprine, a 
labor supressant, before delivery. Wyszogrodski et al. (11) showed that injections of $0.5 \mathrm{mg}$ of isoxsuprine to 28-d-old rabbit fetuses $3 \mathrm{~h}$ before delivery increased the lung stability of the rabbits after delivery. This increase in stability, the authors felt, might be a result of an increase in the amount of alveolar surface-active material. Recently, Corbet et al. (15) demonstrated that this stabilizing influence of isoxsuprine could be blocked by propranolol but not by phenoxybenzamine. Olsen (6) found that isoproterenol, in a single injection to a rat, caused a decrease in the number of lamellar bodies per type II "cell profile" and an increase in the phospholipid content of lung lavages; this effect could be blocked by propranolol. Oyarzún and Clements (12, 16) found that the hyperventilation-stimulated release of phospholipid into lung lavage could be inhibited by propranolol and sotalol. The results of our study are compatible with these in vivo experiments and may help to explain these observations by demonstrating that isolated type II cells respond directly to $\beta$-adrenergic agonists. Recently, Oyarzún and Clements (12) confirmed that our findings with type II cells are relevant in vivo. They demonstrated that terbutaline administered via the pulmonary artery can increase the amount of phospholipid and DSPC in lung lavage; this increase was blocked by propranolol. There is thus reasonable evidence that $\beta$-adrenergic stimuli can increase the release of components of lung surfactant, but, of course, the overall role of adrenergic stimuli in the control of surfactant flux in states of health, stress, and disease is not known at the present time.

If the secretion of pulmonary surfactant from type II cells is, at least in part, under adrenergic control, the source of such adrenergic control remains a matter of speculation. At first consideration, the adrenal medulla would seem to be the most likely source of catecholamines. It may be that intrapulmonary sources of adrenergic stimulation also exist, for both parasympathetic and sympathetic nerves to the lung contain efferent fibers (59). However, it is not well accepted that nerves are commonly found distal to the terminal bronchioles. Meyrick and Reid (60), working with rats, reported that nerve endings are rare in alveolar walls. Moreover, when the authors did find nerve endings, those nerve endings resembled sensory rather than motor neurons. Hung et al. (61), working with mice, described two distinct types of enlarged axons in the alveolar walls. These workers frequently found axons resembling sensory nerve endings close to alveolar type II cells. They found, but less frequently, a second type of nerve ending closely associated with type II cells. Nerve endings of this second type were "packed with many dense core vesicles" and Hung et al. speculated that these endings might serve a motor function. This second type of nerve ending did not have typical ultrastructural characteristics of either adrenergic or cholin- ergic fibers. To decide whether or not these nerve endings have a functional relationship to alveolar type II cells will require further study.

Several research groups have presented evidence that the secretion of lung surfactant may be mediated by cholinergic mechanisms. We have not found that cholinergic agonists or antagonists alter the release of DSPC from type II cells isolated with trypsin or elastase. This lack of response could be because of damage of a cell surface receptor by the isolation procedure, but it could also be that isolated cells do not respond normally because the cells are isolated. Isolated cells are different in several important respects from cells in the lung: the isolated cells may have lost cell polarity and normal cell-cell interactions and they do not receive physical stimuli produced by the normal process of ventilation. These anatomical and physical factors may be important in the regulation of surfactant secretion.

It is possible, however, that in whole animal studies cholinergic stimuli do not affect type II cells directly. Several different investigators (5-8) have presented data that suggest that pilocarpine stimulates secretion of surfactant; in some experiments $(6-8)$ the pilocarpine effect was inhibited by atropine. These workers interpreted their results as evidence that the secretion of surfactant is under cholinergic control, which may be the correct interpretation. However, it is well established (62-64) that pilocarpine stimulates secretion of catecholamines from the adrenal medulla and that this stimulation can be inhibited by atropine. Therefore, pilocarpine might act indirectly, by stimulating the release of catecholamines, to alter surfactant secretion. The recent work of Corbet et al. (15), in which the pilocarpine effect on the pressure-volume curve of fetal rabbit lungs was blocked by propranolol, as well as atropine, suggests this may well be the case. Other substances that stimulate secretion of surface-active material, such as thyroid hormone, may also act indirectly, either by altering the content of catecholamines in the adrenal medulla (65) or by altering cellular responsiveness to adrenergic compounds (66).

Of course, more than one class of pharmacologic compounds might directly stimulate type II cells to secrete surface-active material. Oyarzún and Clements (3) have shown that acetylcholine, infused into one pulmonary artery, increased the phospholipid recovered in lavage of the ipsilateral lung. This finding could be the result of a direct stimulation of type II cells by acetylcholine-induced release of other mediators (prostaglandins or adrenergic agonists), with only a secondary effect on type II cells. Further experiments, both with isolated cells and with whole animals, are needed to test these possibilities.

Thus, whether alveolar type II cells, as we isolate them, are unable to respond to cholinergic stimuli be- 
cause of a loss of function, or whether cholinergic stimuli in vivo act only indirectly (through the adrenal medulla and speculative intrapulmonary mechanisms) remains unclear. There may well be several factors that stimulate secretion of pulmonary surfactant. We have shown that isolated alveolar type II cells release DSPC in response to direct $\beta$-adrenergic stimulation. It seems likely to us that secretion of surface-active material in vivo is modulated by $\beta$-adrenergic mechanisms acting directly on type II cells. Our results do not rule out the participation of other factors in the regulation of surfactant secretion in the whole animal.

\section{ACKNOWLEDGMENTS}

The authors thank Mr. Leonard Berry for technical assistance, Doctors John A. Clements, Paul Insel, Mary Williams, and Bradley Benson for advice during the execution of these experiments, and Doctors John A. Clements and Robert Greenleaf for critical review of the manuscript.

This work was supported by National Heart, Lung, and Blood Institute Program Project grant HL-06285 and Specialized Center of Research in Pulmonary Disease grant HL-19185.

\section{REFERENCES}

1. McClenahan, J. B., and A. Urtnowski. 1967. Effect of ventilation on surfactant, and its turnover rate. J. Appl. Physiol. 23: 215-220.

2. Wyszogrodski, I., K. Kyei-Aboagye, H. W. Taeusch, Jr., and M. E. Avery. 1975. Surfactant inactivation by hyperventilation: conservation by end-expiratory pressure. $J$. Appl. Physiol. 38: 461-466.

3. Oyarzún, M. J., and J. A. Clements. 1977. Ventilatory and cholinergic control of pulmonary surfactant in the rabbit. J. Appl. Physiol. 43: 39-45.

4. Tooley, W., R. Gardner, N. Thung, and T. Finley. 1961. Factors affecting the surface tension of lung extracts. Fed. Proc. 20: 428.

5. Goldenberg, V. E., S. Buckingham, and S. C. Sommers. 1969. Pilocarpine stimulation of granular pneumocyte secretion. Lab. Invest. 20: 147-158.

6. Olsen, D. B. 1972. Neurohumoral-hormonal secretory stimulation of pulmonary surfactant in the rat. Physiologist. 15: 230 .

7. Morgan, T. E., and B. C. Morgan. 1973. Surfactant synthesis, storage and release by alveolar cells. In Respiratory Distress Syndrome. C. A. Villee, D. B. Villee, and J. Zuckerman, editors. Academic Press, Inc., New York. $117-127$.

8. Massaro, D. 1975. In vivo protein secretion by lung. Evidence for active secretion and interspecies differences. J. Clin. Invest. 56: 263-271.

9. Corbet, A. J. S., P. Flax, and A. J. Rudolph. 1976. Reduced surface tension in lungs of fetal rabbits injected with pilocarpine. J. Appl. Physiol. 41: 7-15.

10. Kero, P., T. Hirvonen, and I. Välimäki. 1973. Prenatal and postnatal isoxsuprine and respiratory-distress syndrome. Lancet. II: 198.

11. Wyszogrodski, I., H. W. Taeusch, Jr., and M. E. Avery. 1974. Isoxsuprine-induced alterations of pulmonary pressure-volume relationships in premature rabbits. Am. J. Obstet. Gynecol. 119: 1107-1111.

12. Oyarzún, M. J. and J. A. Clements. 1978. Control of lung surfactant by ventilation, adrenergic mediators, and prostaglandins in the rabbit. Am. Rev. Respir. Dis. 117: 879-891.

13. Stahlman, M. T., M. E. Gray, S. Lieu, and F. Chytil. 1974. The role of cyclic AMP in lamellar body synthesis and secretion. Pediatr. Res. 8: 196.

14. Lawson, E. E., E. B. Brown, J. S. Torday, D. L. Madansky, and H. W. Taeusch, Jr. 1977. Influence of epinephrine on fetal pulmonary fluid production and surfactant release. Physiologist. 20: 55.

15. Corbet, A. J. S., P. Flax, and A. J. Ruldolph. 1977. Role of autonomic nervous system controlling surface tension in fetal rabbit lungs. J. Appl. Physiol. 43: 1039-1045.

16. Oyarzún, M. J., and J. A. Clements. 1977. Ventilation $(\dot{V})$, prostaglandins (PGs) and autonomic mediators in regulation of pulmonary alveolar surfactant content in rabbits. Fed. Proc. 36: 541.

17. Sorokin, S. P. 1970. The cells of the lungs. In Conference on the Morphology of Experimental Respiratory Carcinogenesis. P. Nettesheim, editor. U. S. Atomic Energy Commission, Gatlinberg, Tenn. 3-43.

18. Smith, B. T. 1977. Cell line A 549: a model system for the study of alveolar type II cell function. Am. Rev. Respir. Dis. 115: 285-293.

19. Fisher, A. B., and L. Furia. 1977. Isolation and metabolism of granular pneumocytes from rat lungs. Lung. 154: 155-165.

20. Kikkawa, Y., and K. Yoneda. 1974. The type II epithelial cell of the lung. I. Method of isolation. Lab. Invest. 30: 76-84.

21. King, R. J. 1977. Metabolic fate of the apoproteins of pulmonary surfactant. Am. Rev. Respir. Dis. 115(6, part 2): 73-79.

22. Mason, R. J., M. C. Williams, R. D. Greenleaf, and J. A. Clements. 1977. Isolation and properties of type II alveolar cells from rat lung. Am. Rev. Respir. Dis. 115: 1015-1026.

23. Mason, R. J., M. C. Williams, and L. G. Dobbs. 1977. Secretion of disaturated phosphatidylcholine by primary cultures of type II alveolar cells. In Pulmonary Macrophage and Epithelial Cells. Proceedings of the 16th Annual Hanford Biology Symposium. C. L. Sanders, R. P. Schneider, G. E. Dagle, and H. A. Ragan, editors. Technical Information Center, Energy Research and Development Administration, Springfield, Va. 280-297.

24. Kono, T. 1969. Destruction and restoration of the insulin effector system of isolated fat cells. J. Biol. Chem. 244: 5777-5784.

25. Mangos, J. A., N. R. McSherry, F. Butcher, K. Irwin, and T. Barber. 1975. Dispersed rat parotid acinar cells. I. Morphological and functional characterization. Am. J. Physiol. 229: 553-559.

26. Lefkowitz, R. J., C. Mukherjee, L. E. Limbird, M. G. Caron, L. T. Williams, R. W. Alexander, J. V. Mickey, and R. Tate. 1976. Regulation of adenylate cyclase coupled $\beta$-adrenergic receptors. Recent Prog. Horm. Res. 32: 597-630.

27. Dobbs, L., and R. Mason. 1977. Terbutaline-induced secretion of disaturated phosphatidylcholine from pulmonary alveolar type II cells. J. Cell Biol. 75: 375 a. (Abstr.)

28. Dobbs, L., and R. Mason. 1978. The effect of $\beta$-adrenergic agonists on the release of disaturated phosphatidylcholine from isolated pulmonary alveolar type II cells. Am. Rev. Respir. Dis. 117: 331. (Abstr.)

29. Erlanger, B. F., N. Kokowsky, and W. Cohen. 1961. The preparation and properties of two new chromogenic substrates of trypsin. Arch. Biochem. Biophys. 95: 271-278. 
30. Hummel, B. C. W. 1959. A modified spectrophotometric determination of chymotrypsin, trypsin, and thrombin. Can. J. Biochem. Physiol. 37: 1393-1399.

31. Rinderknecht, H., and R. M. Fleming. 1975. A new, highly sensitive and specific assay for chymotrypsin. Clin. Chim. Acta 59: 139-146.

32. Phillips, H. J. 1973. Dye exclusion tests for cell viability. In Tissue Culture. Methods and Applications. P. F. Kruse, Jr. and M. K. Patterson, Jr., editors. Academic Press, Inc., New York. 406-408.

33. Barber, R., L. A. Kelly, R. F. McGuire, and R. W. Butcher. 1977. Distortion of cyclic AMP responses to catecholamine due to destruction of the hormone.J. Cyclic Nucleotide Res. 3: 249-261.

34. Fanestil, D. D., and C. H. Barrows, Jr. 1965. Aging in the rotifer. J. Gerontol. 20: 462-469.

35. Hayflick, L., and P. S. Moorhead. 1961. The serial cultivation of human diploid cell strains. Exp. Cell Res. 25: $585-621$.

36. W. W. Nichols, D. G. Murphy, V. J. Cristofalo, L. H. Toji, A. E. Greene, and S. A. Dwight. 1977. Characterization of a new human diploid cell strain, IMR-90. Science (Wash. D. C.). 196: 60-63.

37. Mason, R. J., G. Huber, and M. Vaughan. 1972. Synthesis of dipalmitoyl lecithin by alveolar macrophages. J. Clin. Invest. 51: 68-73.

38. Folch, J., M. Lees, and G. H. Sloane Stanley. 1957. A simple method for the isolation and purification of total lipides from animal tissues. J. Biol. Chem. 226: 497-509.

39. Mason, R. J., J. Nellenbogen, and J. A. Clements. 1976. Isolation of disaturated phosphatidylcholine with osmium tetroxide. J. Lipid Res. 17: 281-284.

40. Snyder, F. 1964. Radioassay of thin-layer chromatograms: a high-resolution zonal scraper for quantitative $\mathrm{C}^{14}$ and $\mathrm{H}^{3}$ scanning of thin-layer chromatograms. Anal. Biochem. 9: $183-196$.

41. Persson, K., and K. Persson. 1972. The metabolism of terbutaline in vitro by rat and human liver $\mathrm{O}$-methyltransferases and monoamine oxidases. Xenobiotica. 2: 375382.

42. Maguire, M. E., P. M. Van Arsdale, and A. G. Gilman. 1976. An agonist-specific effect of guanine nucleotides on binding to the beta adrenergic receptor. Mol. Pharmacol. 12: 335-339.

43. Vulliemoz, Y., M. Verosky, and L. Triner. 1975. Effect of albuterol and terbutaline, synthetic beta adrenergic stimulants, on the cyclic 3',5'-adenosine monophosphate system in smooth muscle. J. Pharmacol. Exp. Ther. 195: 549-556.

44. Furchgott, R. F. 1972. The classification of adrenoceptors (adrenergic receptors). An evaluation from the standpoint of receptor theory. In Catecholamines. Handbook of Experimental Pharmacology. Vol. 33. H. Blaschko and E. Muscholl, editors. Springer-Verlag GmbH, Berlin, West Germany. 283-335.

45. Patil, P. N., D. D. Miller, and U. Trendelenburg. 1975. Molecular geometry and adrenergic drug activity. Pharmacol. Rev. 26: 323-392.

46. Williams, L. T., R. Snyderman, and R. J. Lefkowitz. 1976. Identification of $\beta$-adrenergic receptors in human lymphocytes by $(-)\left[{ }^{3} \mathrm{H}\right]$ alprenolol binding. J. Clin. Invest. 57: 149-155.

47. Cheng, Y., and W. H. Prusoff. 1973. Relationship between the inhibition constant $\left(K_{l}\right)$ and the concentration of inhibitor which causes 50 percent inhibition $\left(I_{50}\right)$ of an enzymatic reaction. Biochem. Pharmacol. 22: 30993108.

48. Mangos, J. A., N. R. McSherry, T. Barber, S. N. Arvanitakis, and V. Wagner. 1975. Dispersed rat parotid acinar cells. II. Characterization of adrenergic receptors. Am. J. Physiol. 229: 560-565.

49. Day, A. J., D. Phil, H. A. I. Newman, and D. B. Zilversmit. 1966. Synthesis of phospholipid by foam cells isolated from rabbit atherosclerotic lesions. Circ. Res. 19: 122131.

50. Peters, T. J., M. Müller, and C. deDuve. 1972. Lysosomes of the arterial wall. I. Isolation and subcellular fractionation of cells from normal rabbit aorta. J. Exp. Med. 136: 1117-1139.

51. Phillips, H. J. 1972. Dissociation of single cells from lung or kidney tissue with elastase. In Vitro (Rockville). 8: $101-105$.

52. Callingham, A. 1975. Catecholamines in blood. Handb. Physiol. 6(Sect. 7 Endocrinology): 427-445.

53. Carlström, S., editor. 1970. Studies on terbutaline, a new selective bronchodilating agent. Acta Med.Scand. Suppl. 512: 7-24.

54. Hanoune, J., D. Stengel, M-L. Lacombe, G. Feldmann, and E. Coudrier. 1977. Proteolytic activation of rat liver adenylate cyclase by a contaminant of crude collagenase from Clostridium histolyticum. J. Biol. Chem. 252: 2039-2045.

55. Wallach, D., W. Anderson, and I. Pastan. 1978. Activation of adenylate cyclase in cultured fibroblasts by trypsin. $J$. Biol. Chem. 253: 24-26.

56. Young, S. L., and D. F. Tierney. 1972. Dipalmitoyl lecithin secretion and metabolism by the rat lung. Am.J. Physiol. 222: 1539-1544.

57. Jobe, A. 1977. The labeling and biological half-life of phosphatidylcholine in subcellular fractions of rabbit lung. Biochim. Biophys. Acta 489: 440-453.

58. Dobbs, L. G., and R. J. Mason. 1978. Stimulation of secretion of disaturated phosphatidylcholine from isolated alveolar type II cells by 12-O-tetradecanoyl-13-phorbol acetate. Am. Rev. Respir. Dis. 118: 705-713.

59. Hirsch, E. F., and G. C. Kaiser. 1969. Innervation of the Lung. Charles C Thomas Publishers, Springfield, Ill. 3-104.

60. Meyrick, B., and L. Reid. 1971. Nerves in rat intra-acinar alveoli: an electron microscopic study. Respir. Physiol. 11: $367-377$.

61. Hung, K., M. S. Hertweck, J. D. Hardy, and C. G. Loosli. 1972. Innervation of pulmonary alveoli of the mouse lung: an electron microscopic study. Am.J.Anat. 135: 477-496.

62. Dale, H. H., and P. P. Laidlaw. 1912. The significance of the supra-renal capsules in the action of certain alkaloids. J. Physiol. 45: 1-26.

63. Feldberg, W., B. Minz, and H. Tsudzimura. 1934. The mechanism of the nervous discharge of adrenaline. $J$. Physiol. 81: 286-304.

64. Douglas, W. W. 1975. Secretomotor control of adrenal medullary secretion: synaptic, membrane, and ionic events in stimulus-secretion coupling. Handb. Physiol. 6(Sect. 7 Endocrinology): 367-388.

65. Bray, G. A., and H. S. Jacobs. 1974. Thyroid activity and other endocrine glands. Handb. Physiol. 3(Sect. 7 Endocrinology): 413-433.

66. Malbon, C. C., F. J. Moreno, R. J. Cabelli, and J. N. Fain. 1978. Fat cell adenylate cyclase and $\beta$-adrenergic receptors in altered thyroid states. J. Biol. Chem. 253: 671678. 